\title{
Learning Cultural Heritage History in Muzium Negara through Role-playing Game
}

\author{
Nor Aiza Moketar ${ }^{1}$, Nurul Hidayah Mat Zain ${ }^{2}$, Siti Nuramalina Johari ${ }^{3}$, Khyrina Airin Fariza Abu Samah ${ }^{4}$ \\ Faculty of Computer and Mathematical Sciences, Universiti Teknologi MARA Cawangan Melaka \\ Kampus Jasin, Melaka, Malaysia
}

\author{
Lala Septem Riza ${ }^{5}$ \\ Department of Computer Science Education \\ Universitas Pendidikan Indonesia, Bandung, Indonesia
}

\author{
Massila Kamalrudin ${ }^{6}$ \\ Innovative Software System \& Services \\ Universiti Teknikal Malaysia Melaka, Melaka, Malaysia
}

\begin{abstract}
The traditional classroom-based teaching and learning of the History subject are ineffective and less interactive, influencing the students' interest and motivation to learn history. Therefore, museum-based learning was proposed to supplement classroom-based learning for effective teaching and learning of the History subject. However, the excursions to the museum are often hindered by issues caused by the geographical location, the museum's policies, and student commitments. The hindrances motivated the researchers to design and develop a role-playing game (RPG) in Muzium Negara (National Museum of Malaysia) known as 'Waktu Silam' to enhance students' interest, motivation, and knowledge on the cultural and historical heritage of Malaysia. A survey questionnaire was distributed to assess the enjoyment level provided by the game. The results showed that $\mathbf{8 4 . 8 \%}$ of participants had experienced the element of enjoyment in this game. This study anticipated enhancing the student interest and knowledge in history, enhancing visitors' experience, and promoting tourism to Muzium Negara. Additionally, the project is expected to include multiplayer functionality to add more interactivity to the game in future works.
\end{abstract}

Keywords-Muzium Negara; history; role-playing games; gamification; museum-based learning; enjoyable

\section{INTRODUCTION}

The History subject was made compulsory and a core subject for students by the Malaysian Ministry of Education in 1989 [1]. The subject has become a compulsory-pass subject for secondary school students sitting for the Malaysian Certificate of Education examination (Sijil Peperiksaan Malaysia/SPM) since 2013 [2][3][4]. This step proved that the History subject is vital for several academic reasons. The History subject's main objective is to foster patriotism spirit towards the nation, creating the spirit of unity among people of different races and embedding a sense of pride to be Malaysians among students [1][2][3][4]. The content of the curriculum has undergone rapid changes since the colonial era until Malaysia achieved independence, and the entire chronology has been recorded in the syllabus.

The syllabus of the History subject in the textbook comprises many facts and figures. Students need to memorize the facts to establish the connection between the chronology and to understand the concept of history [2][5]. As a result, the learners feel disinterested and unenjoyable in learning history

This study is sponsored by the Indonesian Ministry of Research and Technology and Universitas Pendidikan Indonesia. as they cannot sense or comprehend the significance of such historical events [6]. Furthermore, the traditional classroombased learning when teaching history is a teacher-centred approach that is proven ineffective and less interactive in enhancing students' interest, motivation, and knowledge [7]. Traditional storytelling when teaching history can cause boredom among the students.

Additionally, a study by Jaafar and Mohd Noor [7], and Napiah, Awang, Ahmad and Che Dahalan [2] stated that learning history is abstract in nature compared to visiting museums or historical places that are more realistic [2][8]. Students will find it more meaningful and practical to understand the history if they gain the experience and engage with the artefacts in the museum. Napiah et al. [2] showed that learning history in a real museum setting contributes a positive effect and helps students understand history better than in the classroom setting [2]. This scenario is an effective way to assist students in remembering chronological history without solely memorizing the facts.

Museum-based learning was proposed to supplement classroom-based learning for effective teaching and learning in history [2][9]. Students are exposed to the genuine historical artefacts exhibited in the museum through this approach. They will gain new learning experiences by seeing, touching, and interacting with historical materials that are not available in classroom settings. Hands-on history learning will also be more fun and interesting. Furthermore, learning history in a museum setting also enhances the students' understanding of the historical concepts taught in the classroom [8][10]. However, the excursions to the museum are often hindered by several issues due to the geographical location, the museum's policies, and student commitments. Therefore, not every student will obtain the opportunity to visit the museum to explore and experience the exhibition.

The issue has motivated the current study's researchers to develop an RPG known as 'Waktu Silam' to give the targeted users the sense and enjoyment of virtually learning the historical content in the national museum of Malaysia, Muzium Negara. 'Waktu Silam' is in the Malay language, which means "the old days". The researchers implemented game-based learning through the RPG genre to learn historical contents in 
Muzium Negara. Game-based learning is deemed an exciting and effective way of learning when adequately constructed using learning principles as a goal. Besides, the proposed games can enhance students' motivation, encourage engagement, and promote learning [11]. The nature of history as a subject makes it essential for current and emerging instruments established to support the main delivery of instruction [5]. Players with or without the intention to learn history may find history easy and be excited to learn with this game.

The upcoming sections of this paper begin with Section 2 that outlines the study's background that focuses on Muzium Negara's overview, the introduction of game-based learning and RPG, and related works. Subsequently, Section 3 presents the study's design and development, Section 4 elaborates on the results and discussions, while Section 5 concludes the paper.

\section{BACKGROUND OF STUDY}

\section{A. Muzium Negara}

Muzium Negara is the national museum of Malaysia, strategically situated in the heart of the capital city of Kuala Lumpur. The museum was built resembling the Malay palacestyle as a symbol of the guardian of the nation's history. The structure is three-storeys high with 109.7 metres long, 15.1 metres wide, and 37.6 metres at the central point. The building was officially opened on 31st August 1963. The galleries in the museum have been upgraded to represent an exhilarating and state-of-the-art approach to exploring Malaysia's history from the pre-historical era to the present time.

The museum houses four main exhibition galleries, as shown in Fig. 1, namely, the Prehistoric Era, Malay Kingdoms, Colonial Era, and Malaysia Today galleries [12][13]. The Prehistoric Era gallery showcases the evolution of the earth's surface until the origin of Malaysia's earliest inhabitant. Additionally, the gallery outlines the discovery of the Palaeolithic age (200000 years ago) stone tools to the HinduBuddhist temple and relics found in Lembah Bujang. The Malay Kingdom gallery traces the historical timeline of the first Malay Kingdoms in the archipelago, specifically the Malay Peninsula. The gallery also highlighted the glorifying days of the Malacca Malay Kingdom in the 15th century.

Conversely, the exhibition presents the historical chronicles of the control and administration of foreign powers: the Portuguese, Dutch, British, and Japanese, and the subsequent effects on the nation's political, social, and economic situations in the Colonial Era gallery. Finally, the Malaysia Today gallery walks the visitors through the arduous path trodden by the peoples' relentless struggle for independence and the formation of a new nation. The gallery demonstrates the transformation process and achievement gained since Malaya's independence in 1957.

Muzium Negara welcomes many tourists daily, including foreigners and Malaysian students. The museum inspires a more comprehensive understanding of Malaysia and its multiracial composition through collections, exhibitions, research, publications, educational and public programmes. Muzium Negara also bears the responsibility of nurturing, protecting, and publishing information on cultural history and natural heritage. Thus, Muzium Negara plays a crucial role in history authentication and preservation.

\section{B. Game-based Learning and Role-Playing Game}

Game-based learning (RPG) is considered an effective approach for teaching and learning purposes. The application of digital games in education helps to develop interest and motivate learners [14]. It can motivate students to focus their attention on education in an enjoyable and engaging way. In addition, game-based learning also provides an opportunity for students to experience a new learning method where students can be more active in learning sessions. Students gain a chance to experience, take risks, and learn without fear of failure from real-life consequences [11]. Some studies established that games could produce positive learning outcomes, efficient in promoting learning and retention, as well as provide an engaging experience compared to traditional instructional methods [15][16]. For example, a study by Wan Fatimah, Afza, and Mohd Hezri Amir [17] have developed an RPG prototype named Maths Quest to engage and assist children in learning mathematics. The heuristic evaluation in terms of learnability, satisfaction, screen design and performance effectiveness has been conducted and received positive feedback from the participants. A different study by Sung and Hwang [18] also proposed a game-based learning approach to guide students in science courses. The result from the experiment shows that the game helps in promoting students' learning attitudes and motivation as well as improving their learning achievement and self-efficacy.

The RPG is among game genres where the player controls a fictional character (or characters) that embarks on a pursuit in a fantasy world. The RPGs varied range share a parallel emphasis by providing the player with a role that advances and progresses via playing and storytelling experience. However, a robust variation exists across and within the format. The RPG also offers a remarkable opportunity to assess most of the crucial questions in-game studies [14]. Besides, RPGs involve a good storyline and interactions with other objects or characters. The storylines and interactions will provide users with the intended experience made by the developer. RPGs can also be used to develop educational games with such features.

The RPGs provide learning environments that engage collaborative problem solving and distribute apprenticeship when playing and influence digital and print literacy advancement, besides science, math, and computational literacy. Hammer, Schrier, Bowman, and Kaufman [19] highlighted that the RPGs are deeply related to constructivism and sociocultural learning theory. The learning in constructivism happens through hands-on experimentation with a new situation, whereas the learning in sociocultural takes place through the adoption of new social roles. The underlying educational theories for each feature makes it appropriate for learning and explain how it is employed in education [19]. These reasons denote that RPGs can be considered a good educational platform although underrated. 


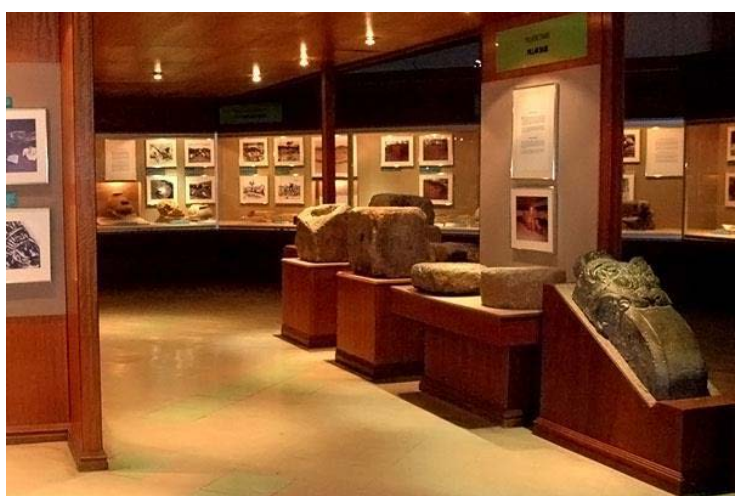

(a)

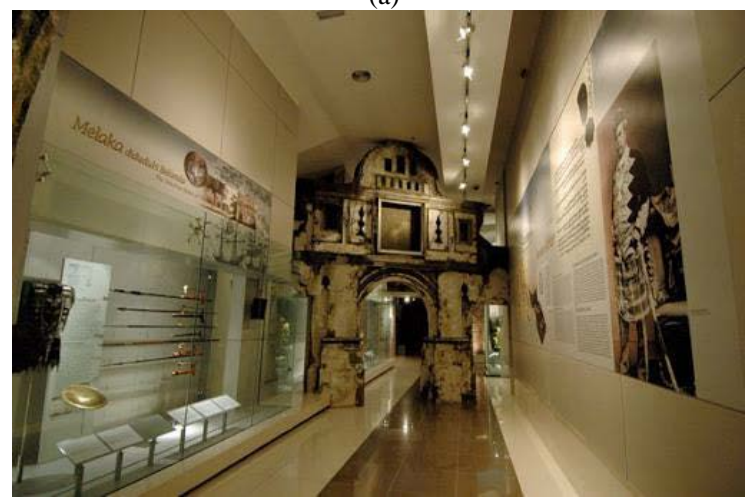

(c)

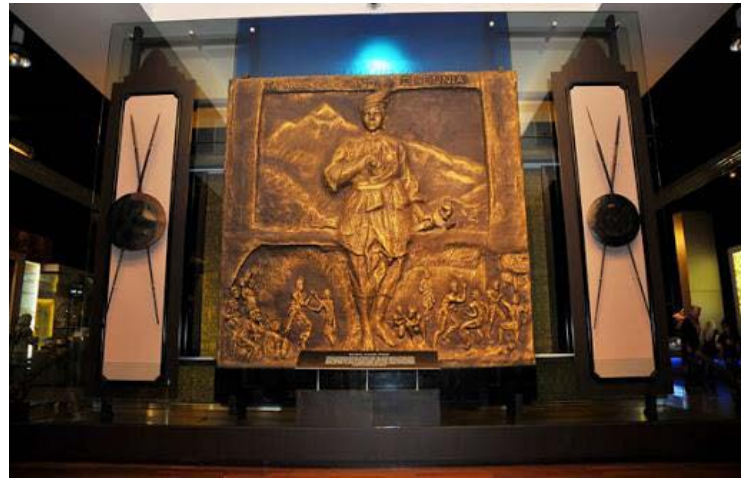

(b)

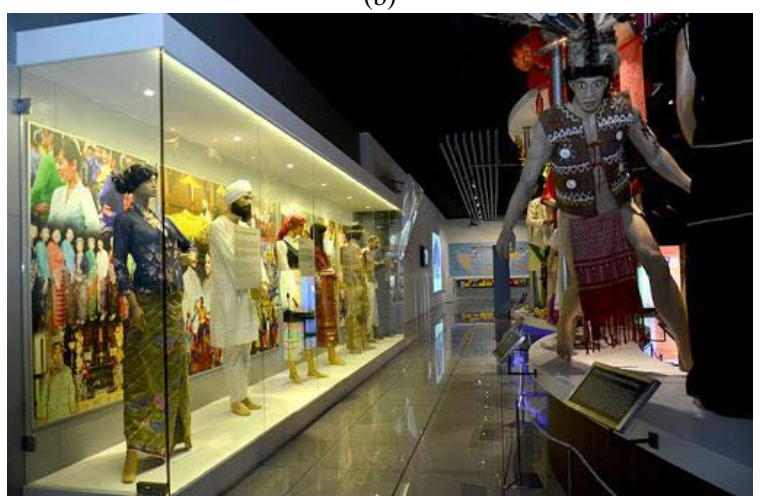

(d)

Fig. 1. The Four Main Galleries in Muzium Negara - (a) Prehistoric Era, (b) The Entrance view of Malay Kingdom Gallery, (c) The Portuguese Section in the Colonial Era Gallery, and (d) Multiracial Section in the Malaysia Today Gallery.

\section{RELATED WORK}

Devising simulated worlds generates an illustrious, sophisticated approach to the design concepts behind virtual worlds. A virtual environment is denoted as the most frequently utilized alternate phrase for platforms otherwise acknowledged as virtual worlds [20]. An avatar or character that mimics the user in the virtual environment can facilitate the user to observe the virtual three-dimensional (3D) environment and induce immersion towards the user. The use of avatar is the medium that allows users to manoeuvre objects in the virtual environment [21]. The virtual environment can be categorized into two general types: multi-user virtual environment (MUVE) and Massively Multiplayer Online RolePlaying Game (MMORPG). According to Döpker, Brockmann and Stieglitz [22], the significant dissimilarity in MUVEs is that the users do not have a specific goal to attain or a startfinish character as in MMORPGs. Thus, integrating RPG elements into a virtual museum can generate users' interest in learning cultural heritage in engaging ways.

The museum's virtualization includes tasks mapping that must be undertaken in a virtual reality museum context for individual tasks in a 3D game [23]. A study by Prasetyo and Suyoto [24] found that implementing the gamification methods at museums can encourage the community to be motivated to visit the museum. Similarly, a study by Araujo, Koenigschulte, and Erb [25] also revealed that implementing interactive games for museum environments can enhance visitor experiences. Another research from López-Martínez, Carrera, and Iglesias [26] found that applying game concepts to museums can contribute to higher levels of cognitive engagement among users. A study by Cosovi'c \& Brkíc [27] also shows that game-based learning is a resolution to transform a traditional museum into a virtual museum and encourage active learning where game-based learning can assist in preserving the cultural heritage. All these approaches integrate game elements into virtual reality museums.

Lepouras and Vassilakis [23] pointed out that education through entertainment is crucial to enhancing user engagement in learning. Approaches utilizing game-integrated entertainment aspects can enhance the user's learning process. Apart from that, digital games can also be used as a persuasive tool to persuade people to learn or improve their knowledge [28]. Therefore, game elements have been applied in various subjects such as Islamic teaching [28], programming [29], and history [30]. In term of History subject, a study by Lee, Talib, Zainon, and Lim [30] have designed and implemented a framework using RPG on the mobile application. The implementation is based on the narrative story of Merong Mahawangsa, a legendary Malaysian warrior. In contrast, our work allows the player to learn historical knowledge from Malaysia's national museum virtually.

\section{METHOdOLOGY}

The researchers implemented the Agile Development Methodology for the development of this project. The phases of the agile development model involved Plan, Design, Develop, Test, Release, and Feedback. Although relatively new, the methodology helps create the project based on thorough evaluation and understanding. The methodology is 
based on implementation over the documentation with consumer involvement and can solve both problems and agility adjustments. Besides, the methodology uses and works through an iterative development framework known as Scrum. Scrum functions in the game development methodology by breaking down game development into a series of tasks named "sprints". The game developers split the game into clusters of associated jobs or features to ease the work with sprints. Additionally, the model stresses small phases with minimal planning and gives moderate access to frequent change requirements in the processes.

The following is the brief explanations of each phase on the Agile Development Methodology Fig. 2:

- Plan: At this stage, the researchers go through the brainstorming session to idealize the game concept, scope and goal. The initial user requirements were also analyzed and documented. The researchers also identified the software and hardware requirements for the development of the project.

- Design: The researchers focused on the plot and storyboard design as defined in the planning stage at the design stage. The details of the design phase are discussed in the next sub-section.

- Develop: The project's development was started once the plot and storyboard designs were agreed upon and confirmed.

- Test: In the testing stage, the verification and validation of the developed project were conducted. The testing ensured that the project had fulfilled the requirements and eliminated any errors or bugs. It is to prevent any undesirable issues from occurring.

- Release: The project was released into production once the testing phase was cleared.

- Feedback: At this stage, the researcher used the convenience sampling method to collect the users' feedback about the developed project. The researchers have distributed survey questionnaires to young adults aged between 17 and 25 years old. The questions were adapted from the eGameFlow model [31]. There are eight dimensions of scale in this model which are the Concentration, Clear Goal, Feedback, Challenge, Autonomy, Immersion, Social Interaction and Knowledge Improvement. Table I shows the description of each dimension.

\section{A. Design Phase}

The design phase focused on the plot and storyboard design. The researchers applied the narrative structure mechanism guided by Freytag's pyramid to design the game's plotline. Freytag's pyramid was initially identified from a successful theatrical tragedy and has been widely applied by game designers [32]. The narratives mechanism is extensively utilized in RPG and plays a crucial role in developing an engaging and meaningful game [33]. Based on Freytag's pyramid, the stories can be segregated into five acts: Exposition, Rising Action, Climax, Falling Action, and
Conclusion. Table II describes the details of each act's narrative purpose in Freytag's pyramid. The researchers adopted Freytag's pyramid to design the narrative structure of the game plot as in Fig. 3.

The game's overall acts are displayed in Fig. 4. First, the player can choose to start the game from the main menu. Then, a cut-scene that introduces the main character and the mission to be accomplished is shown. Next, the player will be prompted to begin the journey to Muzium Negara and explore the exhibition galleries. The player can explore any gallery in the Muzium Negara and interact with the exhibited artefacts. Detailed history information is displayed for each artefact. The game's climax starts when the player is suddenly knocked out and enters a new world, the Prehistoric Era. A non-player character in this new imaginary world will explain the mission to be accomplished to exit the world. Pop-up details are available along the mission mentioning the world's history and the artefacts found. The players can choose to proceed to the next level or end the game once the mission is completed. The following levels include the imaginary world related to the galleries in Muzium Negara, namely, the Malay Kingdom, Colonial Era, and Malaysia Today.

TABLE I. THE DESCRIPTION OF SCALE DIMENSION IN THE EGAMEFLOW MODEL

\begin{tabular}{|l|l|}
\hline $\begin{array}{l}\text { Scale } \\
\text { Dimension }\end{array}$ & Description \\
\hline Concentration & $\begin{array}{l}\text { The game must include activities that stimulate the player's } \\
\text { concentration while avoiding the stress associated with } \\
\text { learning overload, which might cause the player to lose } \\
\text { focus on the game. }\end{array}$ \\
\hline Clear Goal & $\begin{array}{l}\text { The game's objectives and tasks should be clearly stated at } \\
\text { the beginning. }\end{array}$ \\
\hline Feedback & $\begin{array}{l}\text { Feedback enables a player to evaluate the knowledge gap } \\
\text { between their present level of understanding and the } \\
\text { knowledge required to complete the game's task. }\end{array}$ \\
\hline Autonomy & $\begin{array}{l}\text { The game should include challenges that are appropriate for } \\
\text { the player's skill level, with the difficulty of these } \\
\text { challenges increasing as the player's skill level improves. }\end{array}$ \\
\hline Immersion & $\begin{array}{l}\text { The learner should enjoy taking the lead in game play and } \\
\text { having complete control over his or her decisions. }\end{array}$ \\
\hline $\begin{array}{l}\text { Social } \\
\text { Interaction }\end{array}$ & $\begin{array}{l}\text { The game should lead the player into a state of immersion. } \\
\text { socialise. }\end{array}$ \\
\hline $\begin{array}{l}\text { Knowledge } \\
\text { improvement }\end{array}$ & $\begin{array}{l}\text { The game should improve the player's level of knowledge } \\
\text { and skills while meeting the goal of the curriculum. }\end{array}$ \\
\hline
\end{tabular}

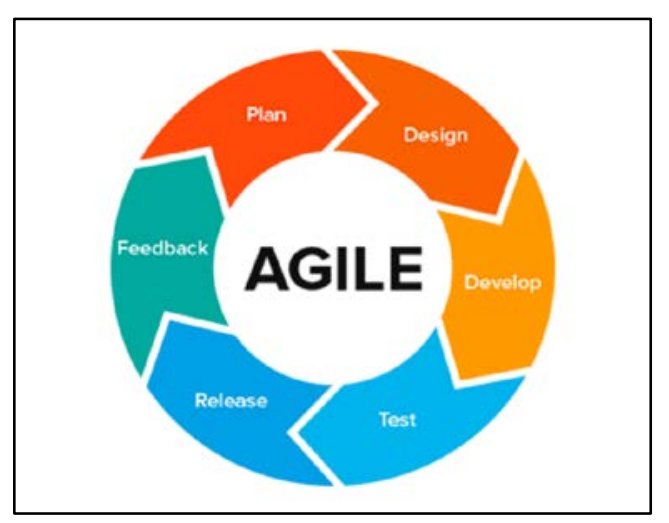

Fig. 2. Agile Development Methodology. 
TABLE II. The NARRative Purpose of EACH Act In FreytaG’s Pyramid

\begin{tabular}{|l|l|}
\hline Act & Narrative Purpose \\
\hline Exposition & Describes the setting, protagonist, and primary conflict. Ends with the inciting moment that drives the story forward. \\
\hline Rising Action & Develops the primary conflict and relates with secondary conflicts. The protagonist overcomes minor obstacles. \\
\hline Climax & The story's turning point. The exact nature of the primary conflict crystallizes, the antagonist is revealed, and the path ahead is made clear. \\
\hline Falling Action & Resolves the primary conflict. Leads to a moment of final suspense, where the outcome is in doubt. \\
\hline Conclusion & The story returns to a state of normality. Ties up loose ends. \\
\hline
\end{tabular}

Unknowingly, he was knocked unconscious. Suddenly, he learns that he was in the history. A helping, beautiful friend seems to understand his situation and wishes to help him. Both of them then seeks out a way to get him out of the illusionary world while in a race with the antagonist. Almost in the end of the journey, the helper was caught by the antagonist as he was losing the race. The protagonist is very doubtfull to help her as the exit is just in front of him.

The main character has agreed to go to Muzium Negara to collect data although he was very lazy

to do so. While going through

the museum, he felt like he was watched from afar.

The story starts as the

user will be introduced

to the main character and

his characteristics
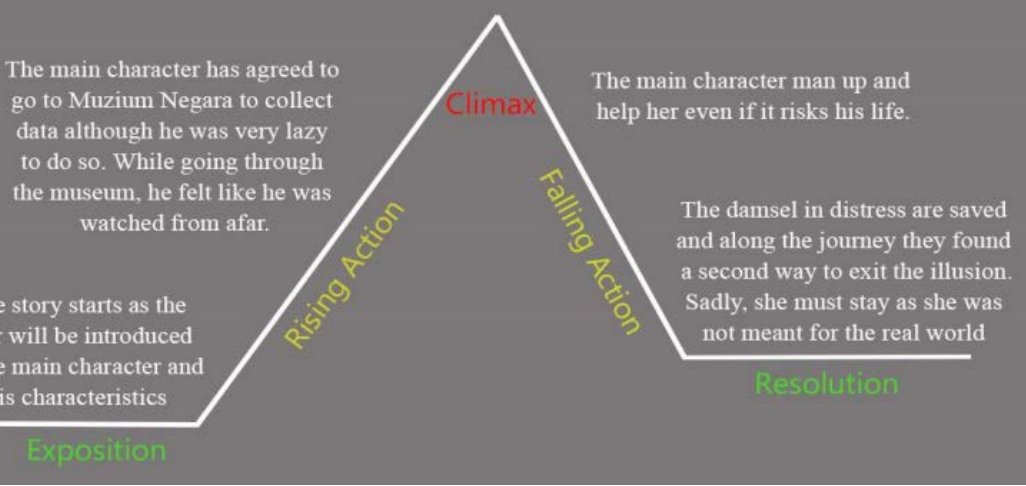

Fig. 3. The Plot Design.

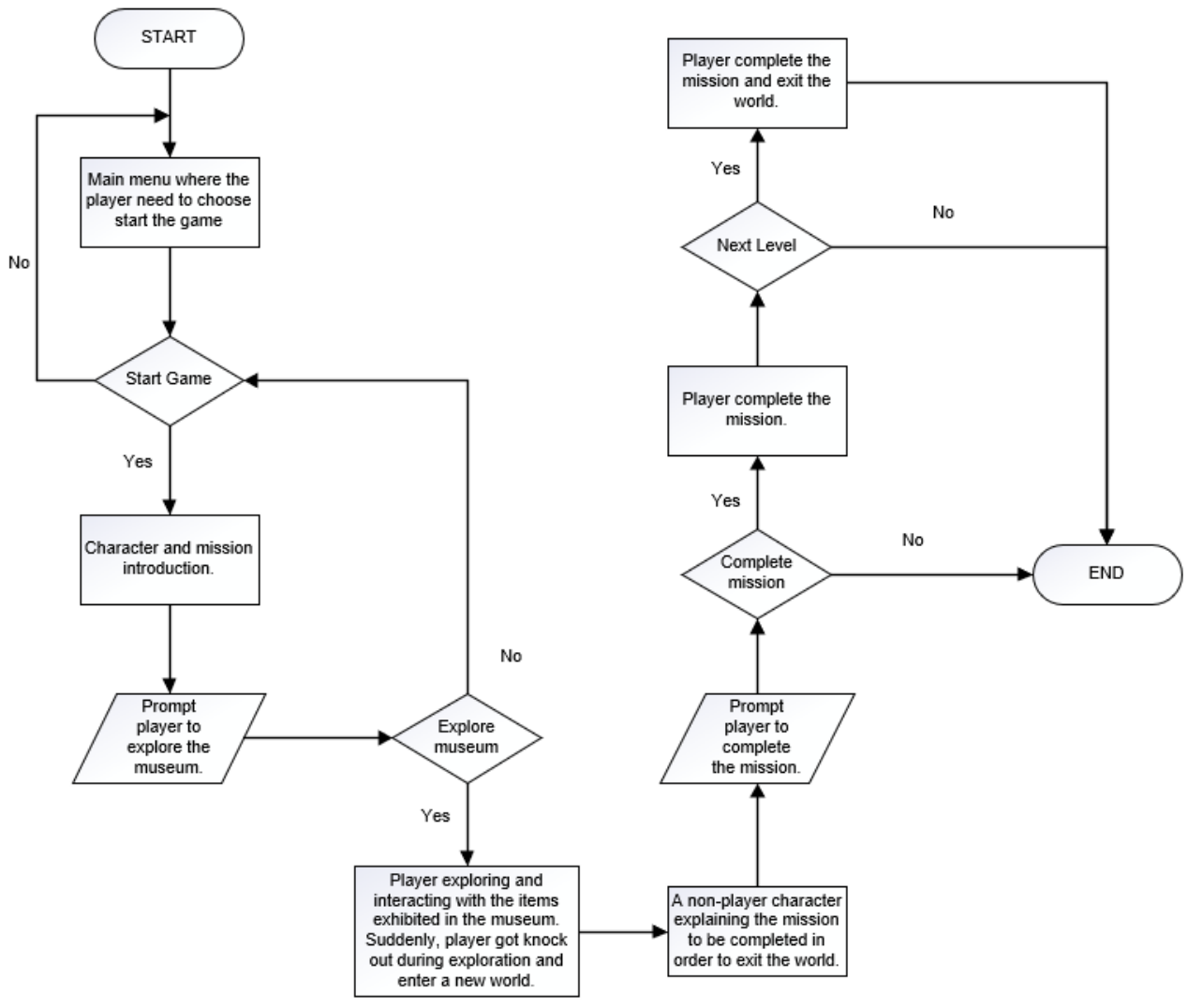

Fig. 4. The Overall Flow of the Game. 


\section{B. Development Phase}

The project's development started with the plot's completion and storyboard design. All the project's models, including the museum and artefacts, were developed using Blender, an open-source 3D creation suite. Fig. 5 shows the museum's exterior design development and its artefacts modelled using Blender. Conversely, the environment scene for the game was developed using Unity, a cross-platform game engine developed by Unity Technologies. Fig. 6 shows the glimpses of the scene produced during the design and development phase.
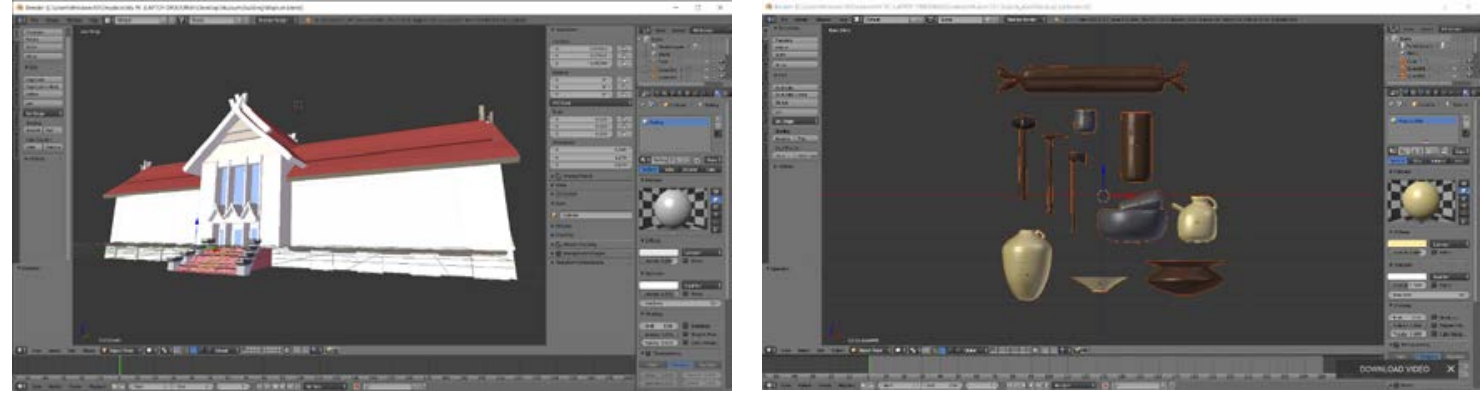

Fig. 5. The Development of 3D Models using Blender.

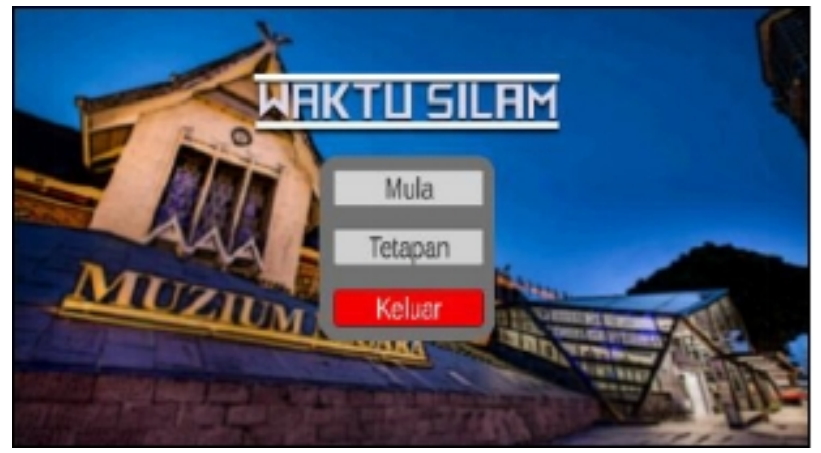

(a)

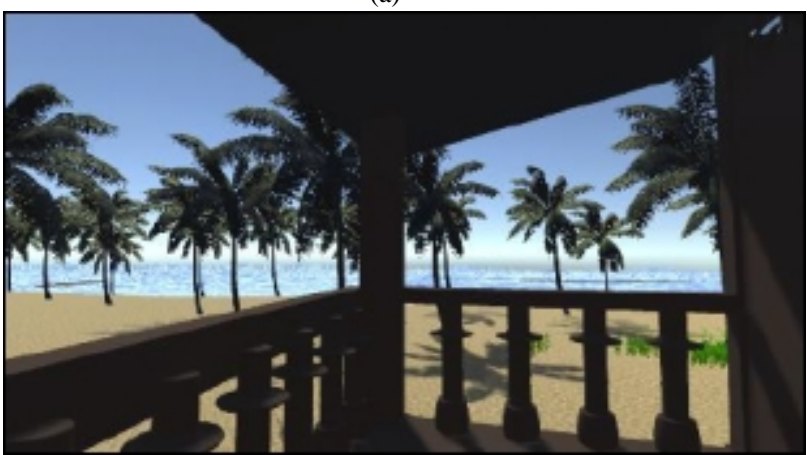

(c)

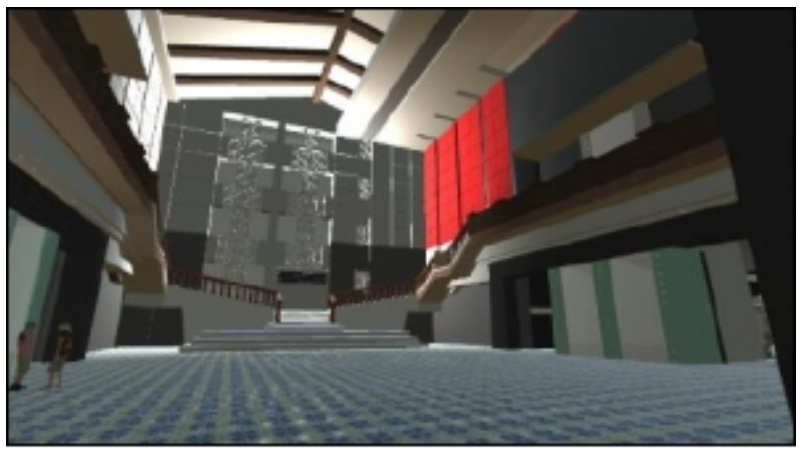

(b)

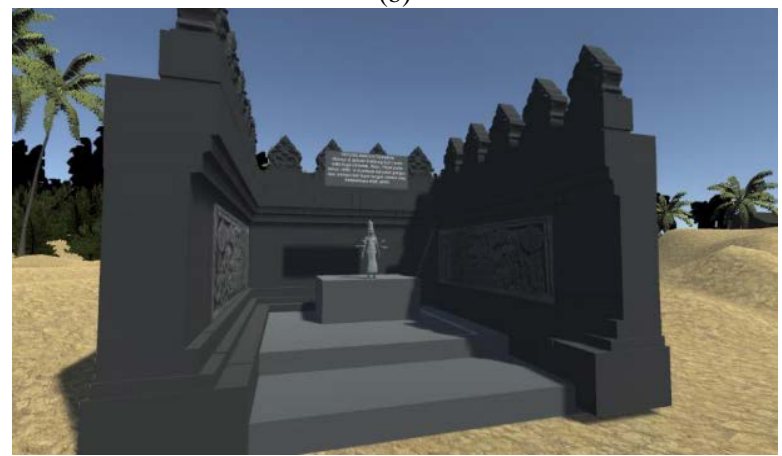

(d)

Fig. 6. The Scene Environment Developed using Unity - (a) The Exterior Design of Muzium Negara, (b) The Interior Lobby of the Museum, (c) The Malay Kingdom Scene and (d) The Artefacts and Monument.

\section{RESUlt AND Discussion}

The researchers adapted the eGameFlow model to evaluate the performance of the developed game. eGameFlow model acts as a scale to measure the respondents' enjoyment experience through its enjoyment factors. The factors adapted incorporate concentration, goal clarity, feedback, challenge, control, immersion, social interaction, and knowledge improvement. Nevertheless, social interaction was not included as the evaluation element because the games were neither developed nor created for multiplayer.

According to the survey results, 32 respondents took part in the evaluation. The majority of respondents were aged 21 to 25 years old, whereas 23 out of 32 respondents (71.9\%) were male. Table II presents the average mean for each element when the descriptive analysis was performed. Next, the analysis calculated the average mean of each element into a total average to determine the evaluation's outcome. The total mean is 4.24 , or $84.8 \%$ of the respondent's enjoyment while playing the game. The analysis results from the survey demonstrate that most respondents agreed that the 'Waktu Silam' game is enjoyable to be played. In addition, the 'Waktu Silam' game was identified to efficiently increase the knowledge on knowing and memorizing history content in the museum. Furthermore, this game can enhance the player's knowledge about Malaysia's history. 
TABLE III. Result of the AVERAge MeAn For EACH EGAMEFlow ElEMENTS

\begin{tabular}{|c|c|c|c|c|}
\hline Elements & Item & Questions & Mean & Average Mean \\
\hline \multirow{8}{*}{ Concentration } & C1 & The game grabs my attention & 4.21 & \multirow{8}{*}{4.13} \\
\hline & $\mathrm{C} 2$ & The game provides content that stimulates my attention & 4.21 & \\
\hline & C3 & Most of the gaming activities are related to the learning task & 4.28 & \\
\hline & $\mathrm{C} 4$ & No distraction from the task is highlighted & 3.93 & \\
\hline & $\mathrm{C} 5$ & Generally speaking, I can remain concentrated in the game & 4.06 & \\
\hline & C6 & I am not distracted from tasks that the player should concentrate on & 4.19 & \\
\hline & C7 & I am not burdened with tasks that seem unrelated & 4.09 & \\
\hline & $\mathrm{C} 8$ & Workload in the game is adequate & 4.06 & \\
\hline \multirow{5}{*}{ Goal Clarity } & G1 & Overall game goals were presented in the beginning of the game & 4.09 & \multirow{5}{*}{4.16} \\
\hline & G2 & Overall game goals were presented clearly & 4.16 & \\
\hline & G3 & Intermediate goals were presented in the beginning of each scene & 4.03 & \\
\hline & G4 & Intermediate goals were presented clearly & 4.28 & \\
\hline & G5 & I understand the learning goals through the game & 4.22 & \\
\hline \multirow{6}{*}{ Feedback } & F1 & I receive feedback on my progress in the game & 4.19 & \multirow{6}{*}{4.10} \\
\hline & F2 & I receive immediate feedback on my actions & 3.81 & \\
\hline & F3 & I am notified of new tasks immediately & 4.09 & \\
\hline & F4 & I am notified of new events immediately & 4.06 & \\
\hline & F5 & I receive information on my success (or failure) of intermediate goals immediately & 4.25 & \\
\hline & F6 & I receive information on my status, such as score or level & 4.19 & \\
\hline \multirow{10}{*}{ Challenge } & H1 & I enjoy the game without feeling bored or anxious & 4.38 & \multirow{7}{*}{4.12} \\
\hline & $\mathrm{H} 2$ & The challenge is adequate, neither too difficult nor too easy & 4.09 & \\
\hline & H3 & The game provides 'hints' in text that help me overcome the challenges & 4.06 & \\
\hline & $\mathrm{H} 4$ & The game provides 'online support' that helps me overcome the challenges & 3.67 & \\
\hline & H5 & The game provides video or audio auxiliaries that help me overcome the challenges & 4.19 & \\
\hline & H6 & My skill gradually improves through the course of overcoming the challenges & 4.19 & \\
\hline & H7 & I am encouraged by the improvement of my skills & 4.16 & \\
\hline & H8 & The difficulty of challenges increases as my skills improved & 3.94 & \\
\hline & H9 & The game provides new challenges with an appropriate pacing & 4.19 & \\
\hline & $\mathrm{H} 10$ & The game provides different levels of challenges that tailor to different players & 4.28 & \\
\hline \multirow{9}{*}{ Autonomy } & A1 & I feel a sense of control the menu (such as start, stop, save, etc.) & 4.84 & \multirow{9}{*}{4.63} \\
\hline & A2 & I feel a sense of control over actions of roles or objects & 4.34 & \\
\hline & A3 & I feel a sense of control over interactions between roles or objects & 4.69 & \\
\hline & A4 & The game does not allow players to make errors to a degree that they cannot progress in the game & 4.59 & \\
\hline & A5 & The game supports my recovery from errors & 4.15 & \\
\hline & A6 & I feel that I can use strategies freely & 4.69 & \\
\hline & A7 & I feel a sense of control and impact over the game & 4.69 & \\
\hline & A8 & I know next step in the game & 4.84 & \\
\hline & A9 & I feel a sense of control over the game & 4.84 & \\
\hline \multirow{7}{*}{ Immersion } & $\mathrm{I} 1$ & I forget about time passing while playing the game & 4.09 & \multirow{7}{*}{4.23} \\
\hline & $\mathrm{I} 2$ & I become unaware of my surroundings while playing the game & 4.38 & \\
\hline & I3 & I temporarily forget worries about everyday life while playing the game & 4.34 & \\
\hline & $\mathrm{I} 4$ & I experience an altered sense of time & 4.15 & \\
\hline & $\mathrm{I} 5$ & I can become involved in the game & 4.22 & \\
\hline & I6 & I feel emotionally involved in the game & 4.38 & \\
\hline & I7 & I feel viscerally involved in the game & 4.06 & \\
\hline \multirow{6}{*}{$\begin{array}{l}\text { Knowledge } \\
\text { Improvement }\end{array}$} & K1 & The game increases my knowledge & 4.06 & \multirow{5}{*}{4.31} \\
\hline & K2 & I catch the basic ideas of the knowledge taught & 4.06 & \\
\hline & K3 & I try to apply the knowledge in the game & 4.38 & \\
\hline & K4 & The game motivates the player to integrate the knowledge taught & 4.69 & \\
\hline & K5 & I want to know more about the knowledge taught & 4.38 & \\
\hline & & Average Mean & & $4.24(84.8 \%)$ \\
\hline
\end{tabular}




\section{CONCLUSION}

The researchers designed and developed an RPG named 'Waktu Silam' as an educational game where the player can virtually learn the historical content in Muzium Negara. The main objective for the game's development is to enhance students' interest, motivation, and knowledge of the Malaysian cultural and historical heritage. Unlike previous research, this initiative allows the player to virtually engage with the artefact in the Muzium Negara and immerse themselves in the virtual world to learn about the past. The evaluation of the game's enjoyment by adapting the eGameFlow model has been conducted. The results showed that the participants experienced about $84.8 \%$ enjoyment while playing the game.

For future work, we plan to include the game's console version and add multiplayer functionality to improve the game's interactivity. Additionally, the researchers also plan to collaborate with Muzium Negara to obtain more information for the game. The collaboration will increase the quality of details and information on the history and enhance the game's quality. The researchers envision that the collaboration will indirectly help boost tourism to Muzium Negara.

\section{ACKNOWLEDGMENT}

The authors would like to acknowledge the Indonesian Ministry of Research and Technology and Universitas Pendidikan Indonesia for funding this work.

\section{REFERENCES}

[1] R. Ahmada, A. Rahim, A. A. Seman, and M. J. Salleh, "Malaysian secondary school history curriculum and its contribution towards racial integration,” Procedia - Soc. Behav. Sci., vol. 7, no. 2, pp. 488-493, 2010, doi: 10.1016/j.sbspro.2010.10.066.

[2] L. Napiah, M. Awang, A. Razaq Ahmad, and S. Che Dahalan, "Museum Based Learning in History Education to Enhance Patriotism among Students," in Proceedings of The 2nd International Conference on Sustainable Development \& Multi-Ethnic Society, 2019, vol. 2, pp. 9599, doi: 10.32698/GCS.0178.

[3] K. G. Kaspin, M. M. Noor, and M. M. Awang, "Perspektif Pelajar Terhadap Kurikulum Sejarah Peringkat Menengah di Malaysia,”J. Pemikir Pendidik., vol. 9, no. December 2018, pp. 12-31, 2018.

[4] N. Syazwani and A. Talib, "Kaedah Pembelajaran Sejarah Berasaskan Lawatan Ke Muzium History Learning Method Based on Museum Visits,” Insa. Online J. Lang. Commun. Humanit., vol. 2, no. June, pp. 45-57, 2019.

[5] V. Zirawaga, A. Olusanya, and T. Maduki, "Gaming in education: Using games a support tool to teach History,” J. Educ. Pract., vol. 8, no. 15, pp. 55-64, 2017, [Online]. Available: https://files.eric.ed.gov/fulltext/EJ1143830.pdf.

[6] G. P. Kusuma, L. K. Putera Suryapranata, E. K. Wigati, and Y. Utomo, "Enhancing Historical Learning Using Role-Playing Game on Mobile Platform,” Procedia Comput. Sci., vol. 179, no. 2019, pp. 886-893, 2021, doi: 10.1016/j.procs.2021.01.078.

[7] C. Chee-Huay and Y. Kee-Jiar, "Why Students Fail in History: A Minor Case Study in Malaysia and Solutions from Cognitive Psychology Perspective,” Mediterr. J. Soc. Sci., vol. 7, no. 1, pp. 517-526, Dec. 2016, doi: 10.5901/mjss.2016.v7n1p517.

[8] S. A. Jaafar and A. Mohd Noor, "Pelaksanaan Pengajaran Dan Pembelajaran Sejarah Di Sekolah-Sekolah Di Malaysia, 1957 - 1989,” SEJARAH, vol. 25, no. 2, pp. 40-57, Dec. 2016, doi: 10.22452/sejarah.vol25no2.3.

[9] A. B. S. Kechot, "Proses Pendidikan Muzium: Satu Kajian Awal,” J. Melayu, vol. 5, no. December 2009, pp. 285-293, 2010.
[10] M. I. H. S. Azman Ligun, Mohd Mahzan Awang, Abdul Razaq Ahmad, "Muzium Sebagai Instrumen Pembelajaran Sejarah Luar Bilik Darjah," J. Kurikulum Pengajaran Asia Pasifik, vol. 5, no. 1, pp. 19-30, 2017.

[11] A. Pho and A. Dinscore, "Game-Based Learning Overview and Definition,” Tips Trends Instr. Technol. Commitee, no. Spring 2015, pp. 1-5, 2015, [Online]. Available: https://acrl.ala.org/IS/wpcontent/uploads/2014/05/spring2015.pdf.

[12] C. Carlos Augusto Bahamón, "Strategies for significant learning in the museum, based on interactive experiences,” ACM Int. Conf. Proceeding Ser., pp. 2-5, 2019, doi: 10.1145/3358961.3358989.

[13] “Department of Museums Malaysia.” http://www.jmm.gov.my/en/ museum/muzium-negara (accessed Jun. 01, 2021).

[14] J. M. Spector, "Emerging educational technologies: Tensions and synergy,” J. King Saud Univ. - Comput. Inf. Sci., vol. 26, no. 1, pp. 510, 2014, doi: 10.1016/j.jksuci.2013.10.009.

[15] J. P. Rowe, E. V. Lobene, B. W. Mott, and J. C. Lester, "Play in the museum: Design and development of a game-based learning exhibit for informal science education,” Int. J. Gaming Comput. Simulations, vol. 9, no. 3, pp. 96-113, 2017, doi: 10.4018/IJGCMS.2017070104.

[16] G. Petri, C. G. von Wangenheim, J. C. R. Hauck, and A. F. Borgatto, "Effectiveness of games in software project management education: An experimental study,” J. Univers. Comput. Sci., vol. 25, no. 7, pp. 840864, 2019.

[17] A. Wan Fatimah, W, S. Afza, and A. L. Mohd Hezri Amir, "Roleplaying game-based learning in Mathematics.," Electron. J. Math. Technol., vol. 4, no. 2, pp. 185-196, 2010.

[18] H.-Y. Sung and G.-J. Hwang, “A collaborative game-based learning approach to improving students' learning performance in science courses," Comput. Educ., vol. 63, pp. 43-51, Apr. 2013, doi: 10.1016/j.compedu.2012.11.019.

[19] J. Hammer, A. To, K. Schrier, S. L. Bowman, and G. Kaufman, "Learning and Role-Playing Games,” in Role-Playing Game Studies, no. April, New York: Routledge, 2018.: Routledge, 2018, pp. 283-299.

[20] C. Girvan, "What is a virtual world? Definition and classification," Educ. Technol. Res. Dev., vol. 66, no. 5, pp. 1087-1100, Oct. 2018, doi: 10.1007/s11423-018-9577-y.

[21] D. Dewez, L. Hoyet, A. Lécuyer, and F. A. Argelaguet Sanz, "Towards 'Avatar-Friendly' 3D Manipulation Techniques: Bridging the Gap Between Sense of Embodiment and Interaction in Virtual Reality,” in Proceedings of the 2021 CHI Conference on Human Factors in Computing Systems, May 2021, pp. 1-14, doi: 10.1145/3411764.3445379.

[22] A. Döpker, T. Brockmann, and S. Stieglitz, "Use Cases for Gamification in Virtual Museums," in Proceedings of the Jahrestagung der Gesellschaft für Informatik, 2013, pp. 2308-232.

[23] G. Lepouras and C. Vassilakis, "Virtual museums for all: employing game technology for edutainment,” Virtual Real., vol. 8, no. 2, pp. 96106, Jun. 2004, doi: 10.1007/s10055-004-0141-1.

[24] N. A. Prasetyo and S. Suyoto, "Design Mobile App for Increase the Visitor Museum using Gamification Method,” TELKOMNIKA (Telecommunication Comput. Electron. Control., vol. 16, no. 6, p. 2791, Dec. 2018, doi: 10.12928/telkomnika.v16i6.10384.

[25] L. M. de Araujo, A. Koenigschulte, and U. Erb, “Enhancing Visitors' Experience - A Serious Game for Museum Environment," in Edulearn10: International Conference on Education and New Learning Technologies, 2010, no. May.

[26] A. López-Martínez, álvaro Carrera, and C. A. Iglesias, "Empowering museum experiences applying gamification techniques based on linked data and smart Objects,” Appl. Sci., vol. 10, no. 16, 2020, doi: 10.3390/APP10165419.

[27] M. Ćosović and B. R. Brkić, "Game-Based Learning in MuseumsCultural Heritage Applications,” Information, vol. 11, no. 1, p. 22, Dec. 2019, doi: 10.3390/info11010022.

[28] M. S. A. Aziz, P. Auyphorn, and M. S. Hamzah, "Exploring the use of digital games as a persuasive tool in teaching Islamic knowledge for muslim children,” Int. J. Adv. Comput. Sci. Appl., vol. 10, no. 6, pp. 109-113, 2019, doi: 10.14569/ijacsa.2019.0100616. 
[29] R. Ibrahim, N. Z. A. Rahim, D. W. H. Ten, R. C. M. Yusoff, N. Maarop, and S. Yaacob, "Student's opinions on online educational games for learning programming introductory,” Int. J. Adv. Comput. Sci. Appl., vol. 9, no. 6, pp. 352-340, 2018, doi: 10.14569/IJACSA.2018.090647.

[30] G. H. Lee, A. Z. Talib, W. M. N. W. Zainon, and C. K. Lim, "Learning history using role-playing game (RPG) on mobile platform," Lect. Notes Electr. Eng., vol. 279 LNEE, no. January 2014, pp. 729-734, 2014, doi: 10.1007/978-3-642-41674-3_104.

[31] F.-L. Fu, R.-C. Su, and S.-C. Yu, "EGameFlow: A scale to measure learners' enjoyment of e-learning games,” Comput. Educ., vol. 52, no. 1, pp. 101-112, Jan. 2009, doi: 10.1016/j.compedu.2008.07.004.
[32] B. Rolfe, C. M. Jones, and H. M. Wallace, "Designing Dramatic Play: Story and Game Structure," in Proceedings of the 2010 British Computer Society Conference on Human-Computer Interaction, BCSHCI 2010, Sep. 2010, no. September, pp. 448-452, doi: 10.14236/ewic/HCI2010.54.

[33] C. Moser and X. Fang, "Narrative Structure and Player Experience in Role-Playing Games,” Int. J. Hum. Comput. Interact., vol. 31, no. 2, pp. 146-156, 2015, doi: 10.1080/10447318.2014.986639. 